Dömötör, Teodóra. ““'Otherness” in America: Hemingway, Hungarians, and Transnationalism.” Hungarian Cultural Studies. e-Journal of the American Hungarian Educators Association, Volume 13 (2020) DOI:

10.5195/ahea.2020.386

\title{
"Otherness" in America: Hemingway, Hungarians, and Transnationalism
}

\section{Teodóra Dömötör}

Abstract: Volatility regarding negotiated subject positions features prominently in Hemingway's works. Yet, his portrayal of Hungarians in the vignette of Chapter VIII and the short story entitled "The Revolutionist" (both found in the collection of In Our Time, 1925) underlines 1920s America's unwillingness to modify preconceived stereotypes about the "other." Both stories have attracted considerable attention among scholars who have analyzed these texts from such perspectives as political ideology and the arts. Aiming to fill a gap in literary criticism, I shall examine the narrative representation of stereotypical approaches to the Hungarian minority with emphasis on societal expectations set by white, Anglo-Saxon, middle-class men in the United States during the 1920s. The values they propagated in society illustrate that the Roaring Twenties was an openly discriminatory decade in which ignoring and sometimes literally attacking the "other" for deviating from the prescribed norms of the era was acceptable. Anxiety about the "other" uncovers a great deal of national insecurity; America's battle with foreigners merges into a battle with itself.

Keywords: Identity, otherness, foreignness, discrimination, transnationalism

Biography: Teodóra Dömötör received her Ph.D. in American Literature from the University of Surrey, UK. She currently works as an Assistant Professor at Károli Gáspár University in Budapest, Hungary. Her primary research concerns twentieth-century transnational American literature with a strong emphasis on the narrative representation of national and gender identity. At present, she investigates the portrayal of immigrant men's infantilization and symbolic castration in the works of modernist American and Hungarian-American emigré writers. She is committed to interdisciplinary research: gender studies, psychoanalysis, social history, and literary theory form the basis of her arguments. Her articles and book reviews have appeared (or are forthcoming) in American and European peerreviewed journals.teodora.domotor@hotmail.com

The narrator in Hemingway's In Our Time (1925) has fixed views regarding various nationalities and ethnic groups. His description of the "other"-represented by Hungarians in the vignette of Chapter VIII and the short story entitled "The Revolutionist" - tends to be driven by stereotypes implied within his enculturation in Middle America. Stereotypes are formed on the basis of individual perception: people gather information, interpret it subjectively, store it in their memory and apply it in their responses. If we consider society to be the basis of such stored knowledge, stereotypes become a kind of public information that members of the community share. Consequently, stereotypes exist in the fabric of the society itself (Macrae et al. 1996: 10). 
Dömötör, Teodóra. ““'Otherness” in America: Hemingway, Hungarians, and Transnationalism.” Hungarian Cultural Studies. e-Journal of the American Hungarian Educators Association, Volume 13 (2020) DOI:

In the aforementioned two stories, Hemingway constantly reminds the reader that the negative characters are Hungarian. He does not simply create unlikable characters who happen to be Hungarian: they represent unpleasantness because they are Hungarian. They are presented as different and unable to integrate into the circle of the other characters. In the stories, they remain outsiders who are separated from the rest of society because of their "otherness." Hemingway does not avoid using derogatory terms for minorities in his novels and short stories ("nigger" [Hemingway 1995: 133], "wops" [Hemingway 1995: 155], "kike" [Hemingway 2004: 142], etc.). He also applies offensive, discriminating language in a commonsensical, natural manner ("He had a hard, Jewish, stubborn, streak" [Hemingway 2004: 9]). Yet do the author's texts really foreground his own hatred of minorities? Based on his underlying dynamics to allude to subtexts, quite the opposite is the case. According to Hemingway's innovative "iceberg principle," which is equivalent to the theory of omission, the narrative refers to hard facts staying on the surface, or above water, in the same way as an iceberg, whereas the supporting language, structure and metaphors operate in an invisible manner (Baker 1972: 117). In line with this technique, Hemingway could be seen as both perpetuating and problematizing racial and ethnic stereotypes at the same time. His Hungarian characters do not come across as unattractive because the author deliberately wished to exhibit his own personal hostility towards East-Central European immigrants; the fact that other characters label Hungarians as worthless only reinforces Hemingway's effort to illustrate that racism and anti-minority sentiment did exist in the American social fabric in the 1920s. Hemingway is eager to highlight this issue in his portrayal of America's prejudice against the "other," but he does not openly pass moral judgement. He mediates human relations in the social milieu with which he is familiar. He regards ethnic difference as an intricate issue in contemporary America, and thus enables his Hungarian characters (and others of different cultural origins) to reveal patterns of marginalization and disavowal.

\section{Foreigners in America: The Historical Background of Discrimination in the 1920s}

Although the term "American Dream" was only coined in 1931 by James Truslow Adams (2012: xx), it is in fact rooted in the Declaration of Independence (1776) which states that all men are created equal and everyone has a right to life, liberty and the pursuit of happiness, promising prosperity to all Americans regardless of social class. Yet the new American Dream after World War I failed to live up to the promise implied in Thomas Jefferson's words. Among several other disturbing events, discrimination was overlooked at the zenith of the Twenties. American history demonstrates that the 1920s witnessed the peak of societal prejudice towards those who ethnically, racially, or in terms of gender were outside the hegemonic power structure that the white, Anglo-Saxon, Protestant core of the American Establishment promoted. Endorsed by the Ku Klux Klan, white supremacy spread nationwide in the Roaring Twenties while anti-immigrant sentiment and exaggerated patriotism also served to further the hatred during the Twenties (Zinn 2005: 203, 382). For example, apart from trying to protect the country from violence and crime initiated by alcohol, the Prohibition Act also underscored America's sense of prejudice primarily against Germany, the increasingly popular beer brewing country. The German nation had already battled the stigma of having dragged America into World War I; now nationalists threatened and abused Germans at daylight, burnt German books, and changed the names of German streets and products (Ogle 2006: 172-173). Labels that were associated with other foreign countries included the Mafia for Italy (Al 
Dömötör, Teodóra. ““'Otherness” in America: Hemingway, Hungarians, and Transnationalism.” Hungarian Cultural Studies. e-Journal of the American Hungarian Educators Association, Volume 13 (2020) DOI:

Capone became a billionaire from illegal alcohol sale, prostitution, and gambling) and conspiracy theories for Eastern Europe (Miller 2004: 302-304).

The case of the Hungarians was particularly interesting as a wave of immigrants who came at the turn of the century included mostly unskilled farm workers who intended to return to Hungary once they had saved up enough money. Accordingly, broken families, poor living conditions and hard work characterized the life of Hungarians in America then. In terms of psychological wellbeing, their perceived or subconscious frustration of not belonging derived from the effect of chronotopic displacement when time and space became out-of-joint in their lives, placing them in a vulnerable condition. Still, at the outbreak of World War I, several Hungarians abandoned the idea of returning to their homeland and settled near the mines and steel furnaces of Ohio, Pennsylvania, New York and New Jersey as well as Illinois, Indiana, Michigan and West Virginia. The interwar years also brought an influx of political expatriates from Hungary. In terms of the number of people who arrived, it was much smaller than previously due to contemporary restrictive immigration policies.

Nonetheless, despite the limitations, between 1922 and 1927 an estimated seventy thousand ethnic Hungarians arrived in America from both Hungary and its neighboring territories (Haines 1996: 133) The Hungarian-American colonies grew rapidly and expanded across the country. While many immigrants worked their way up into skilled factory positions, opening boarding houses was also a popular choice. Boarding houses were run virtually exclusively by women who offered accommodation and meals to working men who had left their families behind and were now alone (Schaefer 2008: 663). Far from being comfortable, these places consisted of crowded rooms, the beds of which were often used by different workers taking turns depending on when they returned home from their shifts. Based on the corruption of the English term "boarding house," immigrants coined new words including burdosház ['boarding house'] and burdosasszony ['boarding lady'] (Mackaman 2017: 47). Cultural anthropologist László Kürti was asked to review a documentary film entitled Boarding House (2015) featuring early twentieth-century Hungarian-American immigrants and their properties in Vintondale, Pennsylvania. He discovered that thousands of items were acquired from a general store, which had also operated as a boarding house for miners in the 1920s and 1930s, and transported to the Open Air Museum of Szentendre, Hungary, in order to illustrate some aspects of contemporary Hungarian-American life. Kürti (2016: 235) questions, however, how much we can actually learn from these objects about the hardship of Hungarian immigrants. Clearly, establishing businesses or making investments needed capital which the immigrants did not have. Instead, many of them worked as miners or agricultural laborers, while others opened market stalls. They worked excessively long hours for low wages-they were usually paid up to forty percent of what a native-born American earned for the same job (Tezla 1987: 20-25). Despite the difficulties they had to face, Hungarians built a strong American ethnic community in which they focused on fundraising to maintain their own religious and cultural heritage (Haines 1996: 134).

The need to form a close-knit (and perhaps closed) community was also triggered by the aforementioned contemporary actions and regulations of the American political system, which aimed at further alienating the US from Europe. Not surprisingly perhaps, the mistreatment of Hungarian immigrants could be practised openly, too. Tibor Glant (1996: 17, 24) examines two cases pertaining to the anti-Hungarian sentiment in early twentieth-century America. Based on 
Dömötör, Teodóra. ““'Otherness” in America: Hemingway, Hungarians, and Transnationalism.” Hungarian Cultural Studies. e-Journal of the American Hungarian Educators Association, Volume 13 (2020) DOI:

historian Herbert Feldman's accounts, he explains that when a foreman was asked about the number of recent fatal accidents, he replied "five men and twelve hunkies," thereby referring to Hungarian-Americans by the latter ethnic slur. Hunkie and bohunk (Bohemian/Hungarian) were commonly-used, degrading terms for Hungarian-Americans at that time. Similarly to the previous case, another example that underlines the dehumanized state of Hungarian immigrants is linked to their work environment. Fourteen Hungarians died because an unsafe platform collapsed beneath them in a factory. Although they had tried to warn their foreman about it, his indifferent reaction was the following: "Never mind! There are many more Hungarians that will replace you!" (Feldman 1931: 48). The "otherness" of these men seemed to make them worthless and dispensable, and it seemed to be the only feature that defined them during the Roaring Twenties.

\section{Hungarians in Hemingway's Texts}

Hemingway's narrative representation of the "other" was directly influenced by Henry James whose essay entitled "The Art of Fiction" (1884) played a significant role in shaping his literary technique (Tyler 2001: 17). James often returned to the theme of the identity-alterity nexus, in which he confronted the Old World/New World dilemma. Although he was born in New York City, he spent most of his adult years in England. Many of his novels depict Americans longing for, travelling to and residing in Europe, which tends to be a recurring topic for him. He exposes dichotomic intricacies by contrasting American materialism and European culturalism, American vulgarity and European sophistication and American dynamism and European petrification. The conflicting poles define the tension between identity and "otherness" (Larsen 1998: 1-15). Hemingway's American characters also travel to or reside in Europe, where they experience cultural identity alteration and behavioral transformation. Like Henry James, Hemingway is a displaced person from a disorderly environment and he endows his characters with the same features. He acknowledges the United States as his country that he cannot escape because his sense of identity derives from there. Even so, his works articulate his ambiguous feelings towards his homeland. He is an observer, a participant, and a storyteller at the same time. His main duty is not only to give an authentic account of his country, but to expose impressions and experiences of the United States from an outsider's perspective. He takes on foreignness as a role. His narrating voice tends to be subjective and his focalization originates in a gaze that has not been dulled by familiarity.

In Our Time (1925) depicts foreigners and, by extension, the problem of discrimination in America through the variety of ethnic groups, including Hungarians, whom Americans label but fail to comprehend. Hemingway exhibits America's prejudicial way of thinking through his narrator's repetitive encounters with foreigners. They appear from the mainstream American's viewpoint: Germans are depicted as whining and ugly ("Cross-Country Snow," "Out of Season," "Soldier's Home"); Greeks as brutal and naive ("On the Quai at Smyrna," Chapter II, "L'Envoi"); Turks as liars and fools ("On the Quai at Smyrna"); Italians as overly patriotic (Chapter VI, "Cat in the Rain"), the Spanish as heroic but fallible (Chapter IX, Chapter XIV) and Hungarians as eternal criminals or victims (Chapter VIII, "The Revolutionist"). In each story, the narrator's portrayal of the "other" tends to be driven by contemporary Middle American stereotypes; as the overall story of In Our Time (1925) progresses, the subplot highlights the transformation of the American narrator's views. Apart from reporting about his homeland and 
Dömötör, Teodóra. ““'Otherness” in America: Hemingway, Hungarians, and Transnationalism.” Hungarian Cultural Studies. e-Journal of the American Hungarian Educators Association, Volume 13 (2020) DOI:

foreign countries, in his documentary-like presentation the narrator also achieves the articulation of his own identity and progresses to establishing the notion of foreignness: what I am not. Alienating details and the loss of the sense of belonging (resulting from his disillusionment in his native society) continue to appear in Hemingway's works. What is important in such writing, says Svend Erik Larsen (1998: 1-15), is that certain literary characters may be alone but never isolated from the "other" who gives them their identity. The "other" forces the individual to analyze himself/herself in relation to the "other", which then leads to the understanding of the "other" as well as the self. Identity and "otherness," therefore, interrelate. The differentiation of the self and the "other" constructs the identity (Fludernik 2007: 263-264).

American national identity is constructed in relation to foreign identities that came to be assimilated into American society. The US brand of multiculturalism has become synonymous with ethnic groups (Moddelmog 1999: 133), yet Hemingway's story insinuates the impossibility of agreement among these groups whose thought process is governed by preconceptions about one another. Alterity is a source of anxiety, therefore "otherness" instantly elicits hostility. Hemingway exposes secrets and acts of disgrace that people would prefer not to reveal. Chapter VIII in In Our Time (1925) leaves no doubt about the unfavorable changes in America during the early twentieth century. The text describes how an American policeman brutally kills two Hungarians without questioning them. Corruption and injustice emerge as America's two predominant features in the story. Driven by the spirit of discrimination, Boyle (with Drevitts watching) commits his disgraceful act against Hungarians "backing their wagon out of an alley"; as Boyle says "I can tell wops a mile off" (Hemingway 1995: 155). The image of 1920s America that emerges in Hemingway's text arises from the fictional representation of factual reality. The names that appear in the fiction play a powerful role in the imitation of reality (Furst 1995: 101102). Boyle is an identifiably Irish name. Unlike before (since the arrival of the first Irish settlers in 1584) when they had been discriminated against, the situation of the Irish in America improved by the 1920s. Irish immigrants and their descendants fulfilled important positions in politics and business (Meagher 2005:3, 10-11, 132-134). Boyle, however, seems to have forgotten his past and he takes advantage of his changed status. He is ignorant of other ethnic groups (he marks the Hungarians as "wops" which is a pejorative racial insult for Italians in America). He labels the two men because they come across as essentially different from him within his racist "logic." This brief vignette illustrates American nativism at its worst while the distinct irony is that the discriminative attitude against Hungarians comes from a fellow foreigner. Hemingway essentially criticizes Irish assimilation which adopts hatred towards the "other" contributing to white American racial policy (Traber 2002: 169).

Interestingly, crucial details are missing in the story: we cannot even be sure whether the murdered victims were indeed Hungarians as only the dead "crooks" could have confirmed this detail. Although the original version of this vignette said, "They're hunkies or wops ain't they?", Hemingway decided to delete the word "hunkies" in order to make Boyle's character more ignorant and bigoted (Cohen 2005: 121). The omitted piece of information, the unsaid and unrepresented, the gap between what is disclosed and what is silenced automatically draws attention to itself, creating presence out of its absence. Robert Paul Lamb (2010: 90) highlights the importance of insufficient information. The non-focalized narrative of Chapter VIII adds to the irony of the story which concentrates on the general anti-immigrant feeling of the 1920s and concerns about the dehumanization of the individual. 
Dömötör, Teodóra. ““'Otherness” in America: Hemingway, Hungarians, and Transnationalism.” Hungarian Cultural Studies. e-Journal of the American Hungarian Educators Association, Volume 13 (2020) DOI:

Apart from the use of deteriorating social values in early twentieth-century United States, this story also stresses the theme of the "fallen man." Boyle, who can kill in cold blood and for no good reason, represents the absurdity of "our time," while the other policeman, Drevitts, signifies the process of decline. "Drevitts got frightened when he found they were both dead" (Hemingway 1995: 155), comments the narrator at first. Nevertheless, a few lines below he adds: "That's all right maybe this time, said Drevitts, but how did you know they were wops when you bumped them?" (Hemingway 1995: 155). Drevitts easily comes to terms with the crime his partner has committed. He is indifferent and cowardly. Although the unjustified action by these two characters may not refer to the viciousness of the entire American nation, their example still facilitates the narrator's portrayal of a general American view on foreigners during the 1920s. The depiction of the police as biased authority corresponds to a sense of superiority (that the Übermensch came to signify for Nazi Germany later on). Unlike the Americans, the Hungarian characters have no name. This anonymity not only suggests their insignificance in the eyes of the locals, but also the society's subconscious repression and automatic rejection of the unknown, the foreign. "They're crooks, ain't they? said Boyle. They're wops, ain't they? Who the hell is going to make any trouble?" (Hemingway 1995: 155).

Examining the stereotype of Hungarians-as-crooks seems to be vindicated when the subsequent short story entitled "The Revolutionist" engages with a penniless and homeless Hungarian, albeit this time in Europe. In this tale, Hemingway applies the same technique of hinting as in Chapter VIII. Here the American narrator meets a Hungarian, "a Magyar, a very nice boy and very shy" (Hemingway 1995: 157) in Italy. The boy's name, again, remains unspecified. We learn that he "suffered very much under the Whites in Budapest" and "Horthy's men had done some bad things to him" (Hemingway 1995: 157). Now he is travelling by rail with the narrator through the Italian countryside in early September 1919. The narrator seems to pity him and offers the Hungarian help by giving him addresses of comrades and nice restaurants in Italy. Yet the story has an underlying historical deficiency. Following World War I, the Austro-Hungarian Empire collapsed. In March 1919, a Communist group took advantage of politically unstable Hungary and formed a government with Béla Kun as leader. Their Red Terror of brutal atrocities against political rivals kept the population in fear for only four months until a successful counter-invasion in August 1919. As the Communist leadership fled the country, the National Army led by Admiral Miklós Horthy took control of Budapest in November 1919. Four months later Admiral Horthy named himself regent of the newly reconstituted Kingdom of Hungary. The White Terror that many link to his name was carried out as a method of cleansing Hungary from individuals associated with the Communist terror (Sugar et al. 1990: 295-318). The young revolutionary in Hemingway's story, therefore, could not possibly have experienced Horthy's White Terror in Budapest before September 1919.

The discrepancy in historical data does not overshadow the point of the story: that is, Americans think of Hungarians as criminals or victims. Keneth Kinnamon (1996: 161-169) argues that the young revolutionist is full of illusions and thus he is deliberately portrayed as a foolish Hungarian who believes in the ultimate victory of world revolution through socialist communism and ends up poor and tortured because he adheres to his principles as a Red communist. Accordingly, the general American public can only regard him as irrational and flawed. Hemingway, however, allows the reader to see the boy from a different angle: from the perspective of an American who is likewise a foreigner in Italy, far away from his native society, 
Dömötör, Teodóra. ““'Otherness” in America: Hemingway, Hungarians, and Transnationalism.” Hungarian Cultural Studies. e-Journal of the American Hungarian Educators Association, Volume 13 (2020) DOI:

similarly vulnerable and transformed by the experience of living abroad even temporarily and who used to have the same faith in his own country and its values. The American narrator can relate to the Hungarian boy because he has experienced naivety and foreignness himself. The final sentence of the story, "The last I heard of him the Swiss had him in jail near Sion" (Hemingway 1995: 158), therefore comes as an unexpected contradiction of the portrayed optimism. The Hungarian boy physically and emotionally climbs up a mountain only to be captured on the other side. The reader is left to guess whether the Swiss would send him back to Hungary (where his potential execution may take place), which is Hemingway's way of contemplating what price is paid for good-natured naivety. Nonetheless, the author refrains from overt moralization; he instead relies on the technique of allusion again. It is by no means a coincidence that while Chapter VIII is narrated in third-person singular, the American narrator in "The Revolutionist" is focalized in first-person singular. This technique points at a gap between the narrator and the "other" (Stewart 2001: 66). The narrator in Chapter VIII watches the victimization of the "other"; he only reports the event, but he is not a participant, he remains seemingly neutral in America. As opposed to this, in "The Revolutionist" he moves closer to the "other". The American narrator interacts with the "other" while he himself is an "other" in Europe. Establishing his own "otherness" proves to be the only way to understand the idea of foreignness.

Exploring one's own identity through the "otherness" of others and thus finding one's place is present in the oeuvre of Hemingway. He endows his main characters with a yearning for understanding, that is, learning from the "other" in order to shape their own identity. He says in Green Hills of Africa (1935): “They certainly were our friends though. They had that attitude that makes brothers, that unexpressed but instant and complete acceptance that you must be [Masai] wherever it is you come from. That attitude you only get from the best of the English, the best of the Hungarians, and the very best Spaniards; the thing that used to be the most clear distinction of nobility when there was nobility. It is an ignorant attitude and the people who have it do not survive, but very few pleasanter things ever happen to you than the encountering of it" (Hemingway 1998: 159). Hemingway's own respect towards Europeans appears in personal letters as well. He wrote the following to his mother in 1918: "This war makes us a lot less fools than we were. For instance, Poles and Italians. I think the officers of the two nations are the finest men I've ever known. There isn't going to be any such thing as 'foreigners' for me after the war now. Just because your pals speak another language shouldn't make any difference. The thing to do is learn that language!" (Villard et al. 1989: 180). Not only does the author employ an array of foreigners in his stories, but the majority of his protagonists are multilingual too. Language works as a social mechanism in the texts; the knowledge of language is a significant step towards social integration (Herlihy 2009: 34-36). Hemingway's multilingual American characters separate themselves from their linguistic origins; by doing so, they are generally inclined to allow for foreign influence in understanding human relations.

The journey of knowledge acquisition, personal development and acceptance of the "other" is portrayed in various ways in Hemingway's In Our Time (1925) as well as his other stories. One of several events in which he participated with the intention of learning and later on documenting in literature was the Spanish Civil War (1936-39). This experience contributed greatly to his own growth concerning "otherness." Although initially an avid supporter of the war, his posthumously published story entitled "Under the Ridge" (1969) expresses his 
Dömötör, Teodóra. ““'Otherness” in America: Hemingway, Hungarians, and Transnationalism.” Hungarian Cultural Studies. e-Journal of the American Hungarian Educators Association, Volume 13 (2020) DOI:

disillusionment about the conduct of battles. The narrator of this story makes propaganda films for the Loyalists in 1937; Hemingway himself was doing the same task then. By the time he started writing "Under the Ridge" in late 1938, however, his initial idealism had dissolved. The story, therefore, dramatizes the effects of the Loyalist leadership's political and military incompetence in a cynical manner (Donaldson 2009: 401). A poignant moment that appears in the text is linked not to political failure, but rather to the author's personal investigation of the notion of "otherness" and, most importantly, the embracing thereof. He goes into considerable amount of detail about the impact of the death of General Paul Lukács. A real-life person and a friend of Hemingway, Lukács had been born Béla Frankl and was better known in Hungary as Máté Zalka, in Hungary. In addition to being a writer himself, under the assumed name of Paul/Pavol Lukács and with the rank of General, he initially commanded the $12^{\text {th }}$ International Brigade and then the $45^{\text {th }}$ Division. He was killed during the Huesca Offensive (Stewart 2012: 172). Should Zalka have returned to the Soviet Union where he used to be a citizen before moving to Spain, he would have faced death for freely associating with Westerners and deviating from the Stalinist norms of socialist realism in his writing (Barta 1990: 79). Every time Hemingway visited Spain as a journalist during the Civil War, he always stayed with the $12^{\text {th }}$ International Brigade and their international group of writers because that is where he felt at home. He became acquainted Lukács there and they instantly became friends. Hemingway said in an interview: "I don't know what kind of a writer he is, but when I listen to him talk, or when I look at him, he always smiles. He is an outstanding man" ['Nem tudom, milyen író, de amikor hallgatom, amikor ránézek, mindig mosolyog. Kitünö ember'] (Hajzer 1987: 5). Hemingway often tried to convince Lukács to have a literary contest between the two of them, but this unfortunately never took place. Learning of Lukács's death, Hemingway is said to have cried: "I don't remember. I know I cried once when somebody died. It must have been Lukasz because Lukasz was the first great loss. Everyone else who had been killed was replaceable" (Vernon 2011:31). Hemingway wrote a moving preface to The Great Crusade (1940) by Gustav Regler (whose commander was Lukács) in which he commemorated his friend and, by extension, emphasized the importance of accepting, appreciating and celebrating the "other." He indirectly called Lukács "irreplaceable" at a time when — according to Glant—Hungarians were considered dispensable "hunkies."

Notwithstanding the American setting of some of Hemingway's stories, it is in Europe that American men acquire profound awareness of foreigners and foreignness. Leaving America is a principal theme and rhetorical device for Hemingway. Such men as Jake Barnes (The Sun Also Rises [1926]), Frederic Henry (A Farewell to Arms [1929]), and Robert Jordan (For Whom the Bell Tolls, [1940]) demonstrate that their expatriate status has substantial consequences for their lives (Herlihy 2009: 28). Hemingway establishes how their ethnic and national "otherness" affects their actions and sense of selfhood abroad. Their lives on foreign soil enable them to reflect upon America's prejudicial attitude towards the "other" (represented by Hungarians in our case) and it also makes them realize even more what their native society lacks. The characters' complex transcultural experience essentially facilitates Hemingway's unpacking of American normativity that affected Hungarians negatively in the Twenties. 
Dömötör, Teodóra. ““'Otherness” in America: Hemingway, Hungarians, and Transnationalism.” Hungarian Cultural Studies. e-Journal of the American Hungarian Educators Association, Volume 13 (2020) DOI:

10.5195/ahea.2020.386

\section{Works Cited}

Baker, Carlos. 1972. Hemingway: The Writer as Artist. Princeton, NJ: Princeton UP.

Barta, Peter I. 1990. "The Writing of History: Authors Meet on the Soviet-Spanish Border." In The Spanish Civil War in Literature. Eds. Pérez, Janet and Aycock, Wendell. Lubbock, TX: Texas Tech UP. 75-85.

Cohen, Milton A. 2005. Hemingway's Laboratory: The Paris in Our Time. Tuscaloosa, AL: U of Alabama Press.

Donaldson, Scott. 2009. Fitzgerald \& Hemingway: Works and Days. New York, NY: Columbia UP.

Feldman, Herman. 1931. Racial Factors in American Industry. New York, NY: Harper \& Brothers.

Fludernik, Monika. 2007. "Identity/Alterity." In The Cambridge Companion to Narrative. Ed. Herman, David. Cambridge: Cambridge UP: 260-73.

Furst, Lilian R. 1995. All is True: The Claims and Strategies of Realist Fiction. Durham, NC: Duke UP.

Glant, Tibor. 1996. "Through the Prism of the Habsburg Monarchy: Hungary in American Diplomacy and Public Opinion during the First World War." University of Warwick, England, October 1996, http://go.warwick.ac.uk/wrap/74531.

Haines, David W. 1996. Refugees in America in the 1990s: A Reference Handbook. Westport, CT: Greenwood Press.

Hajzer, Lajos. 1987. 'Három neve volt' ['He Had Three Names']. Somogyi Néplap 43/137. 5. Hemingway, Ernest. 1995. In Our Time (1925). The Short Stories. New York, NY: Scribner.

----. 1998. Green Hills of Africa (1935). New York, NY: Scribner.

--- 2004. Fiesta: The Sun Also Rises (1926). London: Arrow Books.

Herlihy, Jeffrey. 2009. "Eyes the Same Color as the Sea: Santiago's Expatriation from Spain and Ethnic Otherness in Hemingway's The Old Man and the Sea." The Hemingway Review. Spring. Moscow, ID: U of Idaho Press 28/2. 25-44.

Kinnamon, Keneth. 1996. "Hemingway and Politics." In The Cambridge Companion to Hemingway. Ed. Donaldson, Scott. New York, NY: Cambridge UP. 149-69.

Kürti, László. 2016. "Review Article: Documenting Immigrants, Boarding Houses and Ethnographers. Burdosház Amerikából - Balogh Balázs néprajzkutató nyomában ('A Boarding House from America: In the Footsteps of the Ethnographer, Balázs Balogh')." Hungarian Cultural Studies. https://ahea.pitt.edu/ojs/index.php/ahea/article/view/237/448

Lamb, Robert Paul. 2010. Art Matters: Hemingway, Craft and the Creation of the Modern Short Story. Baton Rouge, LA: Louisiana State UP.

Larsen, Svend Erik. 1998. "The Tacit Other. Identity and Otherness in Two Texts by Henry James". Conference paper. $2^{\text {nd }}$ International Congress of the Greek Association of General and Comparative Literature, Athens, November 8-11.

Mackaman, Thomas. 2017. New Immigrants and the Radicalization of American Labor, 1914-1924. Jefferson, NC: McFarland \& Company, Inc., Publishers

Macrae, C. Neil, Stangor; Charles; and Hewstone, Miles. 1996. Stereotypes \& Stereotyping. New York, NY: Guilford Press. 
Dömötör, Teodóra. ““'Otherness” in America: Hemingway, Hungarians, and Transnationalism.” Hungarian Cultural Studies. e-Journal of the American Hungarian Educators Association, Volume 13 (2020) DOI:

Meagher, Timothy J. 2005. The Columbia Guide of Irish American History. New York, NY: Columbia UP.

Miller, Nathan. 2004. New World Coming: The 1920s and the Making of Modern America. Cambridge, MA: Da Capo Press.

Moddelmog, Debra A. 1999. Reading Desire: In Pursuit of Ernest Hemingway. Ithaca and London: Cornell UP.

Ogle, Maureen. 2006. Ambitious Brew: The Story of American Beer. Orlando, FL: Harcourt Books.

Schaefer, Richard T. 2008. Encyclopedia of Race, Ethnicity, and Society. Thousand Oaks, CA: SAGE Publications, Inc.

Stewart, Jules. 2012. Madrid - the History. London: I.B. Tauris \& Co. Ltd.

Stewart, Matthew. 2001. Modernism and Tradition in Ernest Hemingway's In Our Time. Rochester, NY: Camden House.

Sugar, Peter F.; Hanák, Péter; and Frank, Tibor. 1990. A History of Hungary. Bloomington, IN: Indiana UP.

Tezla, Albert. 1987. "Valahol túl meseországban..." - Az amerikás magyarok, 1895-1920. [“"Somewhere in a Fairyland...” Hungarian Americans, 1895-1920'] Budapest: Európa Könyvkiadó. II. 20-25.

Traber, Daniel S. 2002. "Whiteness and the Rejected Other in The Sun Also Rises." In Ernest Hemingway's The Sun Also Rises: A Casebook. Ed. Wagner-Martin, Linda. New York, NY: Oxford UP. 167-86.

Truslow Adams, James. 2012. The Epic of America (1931). New Brunswick, NJ: Transaction Publishers.

Tyler, Lisa. 2001. Student Companion to Ernest Hemingway. Westport, CT: Greenwood Press.

Vernon, Alex. 2011. Hemingway's Second War: Bearing Witness to the Spanish Civil War. $\mathrm{U}$ of Iowa Press.

Villard, Henry S. and Nagel, James. 1989. Hemingway in Love and War: The Lost Diary of Agnes von Kurowsky, Her Letters, and Correspondence of Ernest Hemingway. Boston, MA: Northeastern UP.

Zinn, Howard. 2005. A People's History of the United States. New York, NY: Harper Perennial Modern Classics. 